\title{
Comparative analysis of models for design of infiltration basins in unpaved roads
}

\author{
Danilo P. da Silva ${ }^{1}$, Fernando F. Pruski ${ }^{2}$, \\ José M. A. da Silva ${ }^{2} \&$ Waldir D. M. Meireles Filho ${ }^{2}$
}

\begin{abstract}
Unpaved roads are of great importance for the economic and social development of a country. Water erosion provoked by the concentration of runoff along the road is a principle cause of its degradation. The construction of infiltration basins for runoff retention on unpaved roads is a usually alternative for the problem solution. The use of more coherent methodologies for designing infiltration basins is fundamental for the appropriate road degradation processes control. Therefore, the objective of this work was to perform a comparative analysis of a methodology for the design of infiltration basins that consider an intense rainfall associated to a determined return period, with a methodology that use all events of a determined precipitation series, and overlapping effects of their respective runoff volumes. According to the obtained results, it was found that the volume calculated for the infiltration basin by the model which considers all events of the precipitation series is greater when the rate of water infiltration into the soil at the basin bottom is lowest.
\end{abstract}

Key words: road erosion, retention basin, detention basin, best management practices, synthetic precipitation series

\section{Análise comparativa de modelos para dimensionamento de bacias de infiltração em estradas não pavimentadas}

\section{RESUMO}

Estradas não pavimentadas são imprescindíveis para o desenvolvimento econômico e social de um país. A erosão provocada pela concentração do escoamento superficial ao longo da estrada é a principal causa da sua degradação. A construção de bacias de infiltração para reter o volume do escoamento superficial proveniente das estradas não pavimentadas, consiste em uma alternativa comumente empregada para a solução do problema. O uso de metodologias mais coerentes para o dimensionamento de bacias de infiltração é fundamental para controlar, de forma mais adequada, o processo de degradação das estradas. Assim, o objetivo deste trabalho foi a realização de uma análise comparativa de uma metodologia para o dimensionamento de bacias de infiltração, que considera uma chuva intensa associada a determinado período de retorno, com uma metodologia que pondera uma série histórica de eventos de precipitação. Evidenciou-se, de acordo com os resultados obtidos, que o volume da bacia de infiltração calculado pelo modelo que leva em consideração todos os eventos da série de precipitação, é maior quando a taxa de infiltração da água no solo no fundo da bacia é menor.

Palavras-chave: erosão em estradas, bacias de retenção, bacias de detenção, práticas conservacionistas, série sintética de precipitação 


\section{INTRODUCTION}

Unpaved roads, also known as unsealed roads or rural roads, are of great importance for the economic and social development of a country (Lugo \& Gucinski, 2000; Crossley et al., 2001; Carvalho et al., 2010). Their existence enable the access of rural population to health services, education, leisure (Gallego et al., 2008a), and transport of agricultural, stock-raising and products of forestry activities (Gallego et al., 2008b).

Water erosion is one of the major factors influencing unpaved roads deterioration (Egan, 1999; Rummer et al., 2000; Machado et al., 2003). Apart from roadbed deterioration, unpaved roads in inappropriate conditions can both lead and aggravate erosion processes in agricultural areas (Jungerius et al., 2002; Nyssen et al., 2002). Furthermore, this process may cause silting and pollution of watercourses (Grace III, 2002; Motha et al., 2004; Forsyth et al., 2006; Thompson et al., 2010).

Due to the role of runoff as the main agent of unpaved roads erosion, its drainage before flow concentration and erosive energy acquirement is of fundamental importance for preventing accentuated damages to the roads (Griebeler et al., 2005). However, the simple act of removing water from roads is not sufficient in the absence of appropriate destination for the flow, which would resume in transferring the problem to road marginal areas. Therefore, the construction of infiltration basins for runoff retention on unpaved roads is alternative of great importance for the control of degradation processes on these roads.

For designing infiltration basins, normally only a single intense rainfall is considered, such as in methodology developed by Pruski et al. (1997). In order to develop appropriate methodology for designing infiltration basin, Silva (2009) proposed a model based not only on one rainfall event, but all events of historical series at the place of interest and consequently, the cumulative effect of its respective runoff events throughout the series.

Based on hypothesis that calculation of required volume to infiltration basins, the adoption of criteria that takes into account the analysis event to event of precipitation is more consistent than one based at a single event associated with a return period of project, this work aims to conduct a comparative analysis of the model developed by Silva (2009) (based on event to event analysis) with the one developed by Pruski et al. (1997) (based on a single event).

\section{MATERIAL AND METHODS}

The model proposed by Pruski et al. (1997), called the Soil Surface Water Balance Method (Pruski, 2009), obtains the maximum runoff volume to be retained by the basin considering the maximum rainfall for a given project return period, such as several other methods developed for designing infiltration basins. The model proposed by Silva (2009) is based on a new concept for designing infiltration basins, which takes into account not only one rainfall event, but all historical series events at the place of interest, as well as the overlapping effects of their respective runoff volumes.
Soil surface water balance method (Pruski et al., 1997)

The Soil Surface Water Balance Method (SSWB) (2005) was developed in order to obtain the maximum surface runoff depth (MRD, in mm). In this model, the volume required for the infiltration basin $\left(\mathrm{V}_{\mathrm{B}}\right)$ is derived from the product of MRD (converted to $\mathrm{m}$ ) by the road area contributing $\left(\mathrm{m}^{2}\right)$ to the infiltration basin.

To obtain MRD a physical model of water balance on soil surface water was used as described by:

$$
\mathrm{MRD}=\mathrm{R}-\mathrm{Ia}-\mathrm{F}
$$

where:

$\mathrm{R}$ - total rainfall depth, $\mathrm{mm}$

Ia - initial abstraction, $\mathrm{mm}$

F - accumulation infiltration, $\mathrm{mm}$

The total rainfall depth corresponding to a time interval $t$ (min) was obtained by:

$$
\mathrm{R}=\frac{\mathrm{i}_{\mathrm{m}} \mathrm{t}}{60}
$$

where:

$i_{m}$ - average maximum rainfall intensity, $\mathrm{mm} \mathrm{h}^{-1}$ (which is constant for a given rainfall and time duration)

$\mathrm{t}$ - rainfall duration (min)

To obtain $\mathrm{i}_{\mathrm{m}}$, the classical rainfall intensity-durationfrequency relationship was used:

$$
i_{m}=\frac{K T^{a}}{(b+t)^{c}}
$$

where:

a, b, c, K - parameters of the precipitation profile equation, dimensionless

Substituting Eq. 3 into Eq. 2 and taking the derivative with respect to time, the instantaneous rainfall intensity $\left(i_{\text {int }}\right)$, in $\mathrm{mm} \mathrm{h}^{-1}$, is obtained:

$$
i_{i n t}=i_{m}\left(1-\frac{c t}{t+b}\right)
$$

Both $i_{m}$ and $i_{\text {int }}$ decrease as $t$ increases. The MSR ends at the instant at which $i_{\text {int }}$ is equal water infiltration into the soil of the roadbed $\left(\mathrm{INF}_{\mathrm{R}}\right)$. Under this condition:

$$
i_{m}\left(1-\frac{c t}{t+b}\right)-I N F_{R}=0
$$

The t value corresponding to MSR was obtained using the Newton-Raphson method.

The values of initial abstraction were determined by the curve number method, using the equation (SCS, 1972): 


$$
\mathrm{Ia}=50,8\left(\frac{100}{\mathrm{CN}}-1\right)
$$

where $\mathrm{CN}$ is the curve number.

The time corresponding to the initial abstraction was obtained using:

$$
\mathrm{t}_{\mathrm{Ia}}=\frac{\mathrm{I}_{\mathrm{a}} 60}{\mathrm{i}_{\mathrm{m}}}
$$

where $t_{\mathrm{Ia}}$ is the time interval from the beginning of the rain to the beginning of the of runoff ( $\mathrm{min}$ )

$$
\mathrm{F}=\frac{\mathrm{INF}_{\mathrm{R}} \mathrm{t}_{\text {inf }}}{60}
$$

where:

$\mathrm{INF}_{\mathrm{R}}$ - rate of water infiltration into the soil of the roadbed, $\mathrm{mm} \mathrm{h}^{-1}$

$\mathrm{t}_{\text {inf }}$ - infiltration period, min (obtained from the equation $\mathrm{t}_{\text {inf }}=\mathrm{t}-\mathrm{t}_{\mathrm{Ia}}$ )

\section{Model proposed by Silva (2009)}

This model uses synthetic precipitation data obtained from the ClimaBr model, developed by Oliveira et al. (2005a; 2005b) and refined by Zanetti et al. (2005) and Baena et al. (2005). From a historical series of rainfall data the ClimaBr model generates the following variables: total precipitated depth, total rainfall duration, time of maximum intensity rainfall and parameters related to the precipitation profile.

The precipitation profile considered in ClimaBr is described by a double exponential function (Figure 1) that represents the variation of the instantaneous precipitation intensity $\left(i_{i}\right)$ as a function of time $(t)$.
A double exponential function that represents the precipitation profile is given as:

$$
i_{i}= \begin{cases}a^{\prime} e^{b^{\prime} t} & 0 \leq t \leq t i_{\max } \\ c^{\prime} e^{-d^{\prime} t} & t_{\max }<t \leq 1,0\end{cases}
$$

where:

a', b', c', d' - parameters of the double exponential function in relation to the precipitation event, dimensionless

$\mathrm{ti}_{\text {max }}$ - time of occurrence of the maximum instantaneous precipitation intensity, dimensionless

From the daily series of rainfall data, calculations are performed to obtain the daily runoff volume. The runoff volume $(\mathrm{RV})$ is derived from the product of runoff depth (RD) by the road area contributing to the infiltration basin.

In the determination of RD it is assumed that runoff starts when $i_{i}$ is greater than the rate of water infiltration into the soil of the roadbed $\left(\mathrm{INF}_{\mathrm{R}}\right)$ at time $\mathrm{t}_{\mathrm{b}}$, and ends when $\mathrm{i}_{\mathrm{i}}$ returns to be equal to $\mathrm{INF}_{\mathrm{R}}$, at time $\mathrm{t}_{\mathrm{e}}$ (Figure 1).

The precipitation depth occurring in the interval between the times $t_{b}$ and $t_{e}$ is obtained from the sum of the value resulting from the integration of the area corresponding to the ascending branch of the precipitation profile, $\mathrm{t}_{\mathrm{b}}$ to $\mathrm{ti}_{\text {max, }}$ and the area corresponding to the descending branch, $\mathrm{ti}_{\text {max }}$ to $t_{\mathrm{e}}$ (Figure 1). The value of $\mathrm{RD}$ is derived from the difference between the precipitation depth occurring during the time interval from $t_{b}$ and $t_{e}$, and the infiltration depth occurring in the roadbed over the same time interval. The infiltration depth is obtained from the product of $\mathrm{INF}_{\mathrm{R}}$ by the time interval in which surface runoff $\operatorname{occurs}\left(\mathrm{t}_{\mathrm{e}}-\mathrm{t}_{\mathrm{b}}\right)$.

The volume stored in the infiltration basin on a given day of the series $\left(\mathrm{V}_{\mathrm{Si}}\right)$ is obtained from the total volume of runoff reaching the basin that day $\left(\mathrm{RV}_{\mathrm{i}}\right)$ and the stored volume remaining from the previous day $\left(\mathrm{V}_{\mathrm{Ri}-1}\right)$. These volumes are obtained by the equations:

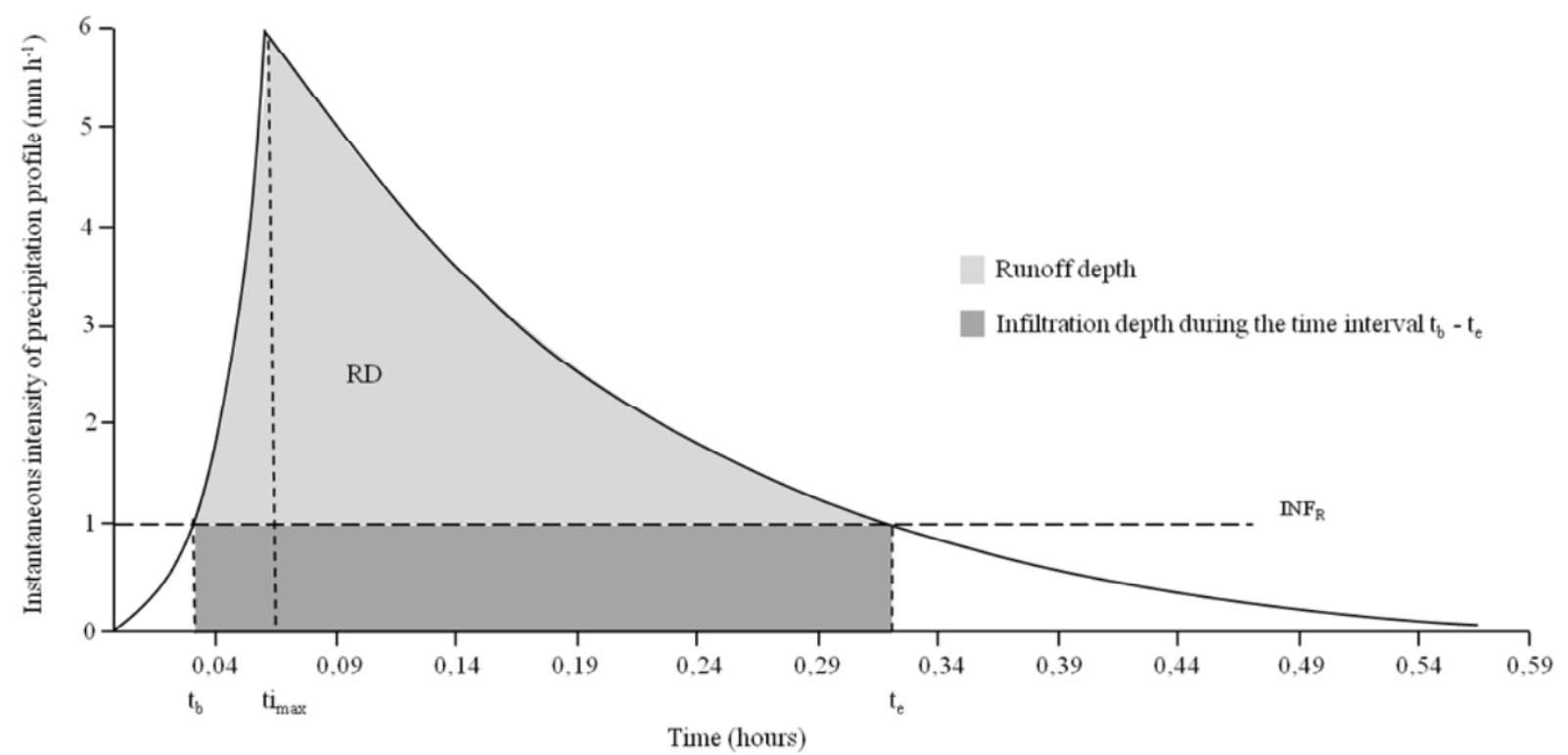

Figure 1. Precipitation profile as a double exponential function 


$$
\mathrm{V}_{\mathrm{Si}}=\mathrm{RV}_{\mathrm{i}}+\mathrm{V}_{\mathrm{R} \mathrm{i}-1}
$$

In the first rainfall of the series, which corresponds to the beginning of the simulations, the value of $\mathrm{V}_{\mathrm{S}}$ is equal to the volume of runoff that occurs on this day. If this volume does not completely infiltrate to the bottom of the basin that day, part of this volume will remain in the basin, corresponding to the value of $\mathrm{V}_{\mathrm{R} \text { i-1 }}$ for the next day.

The values of $\mathrm{V}_{\mathrm{R} i-1}$ are directly related to the geometrical characteristics of the basin (width and slopes) and the water infiltration rate into the soil at the bottom of the basin $\left(\mathrm{INF}_{\mathrm{B}}\right)$. Basins that have lower embankment slopes and greater width tend to have a greater surface area of liquid when full, a fact which implies a greater infiltrated volume for the same $\mathrm{INF}_{\mathrm{B}}$.

The $V_{S}$ values calculations are repeated for all days in the series, in order to obtain a daily series of volumes stored. In each year the highest value of $\mathrm{V}_{\mathrm{S}}$ from the series is identified which provides an annual series of maximum volumes stored in the infiltration basin $\left(\mathrm{V}_{\max }\right)$.

The volume required for the infiltration basin $\left(\mathrm{V}_{\mathrm{B}}\right)$ is obtained by applying the Gumbel distribution to the series of maximum stored volumes. According to the methodology proposed by Kite (1988), to calculate the magnitude of an event for finite series the value of $V_{B}$ is calculated from the following equation:

$$
\mathrm{V}_{\mathrm{B}}=\overline{\mathrm{V}}_{\text {max }}+\mathrm{K}^{\prime} \sigma
$$

where:

$\mathrm{V}_{\max }$ - average of the maximum storage volume, $\mathrm{m}^{3}$

$\mathrm{K}^{\max }$ - frequency factor, dimensionless

$\sigma$ - standard deviation of the maximum quantity stored in each year of the series, dimensionless

The frequency factor for the finite series is calculated as follows:

$$
K^{\prime}=-\left(0,45+0,7797 \ln \left(-\ln \left(1-\frac{1}{\mathrm{~T}}\right)\right)\right)
$$

where $\mathrm{T}$ is the return period, years.

\section{Comparative analysis of models}

The analyses were made based on comparison of VB values obtained by two models. The VB values were calculated considering five return periods $(5,10,15,18$ and 20 years $)$ and five values of water infiltration rate through the basin bottom soil - INFB $\left(2,5,10,15\right.$ and $\left.20 \mathrm{~mm} \mathrm{~h}^{-1}\right)$. The comparison of the VB values was separately made for each $\mathrm{INF}_{\mathrm{B}}$ value, since this variable is not considered in the model proposed by Pruski et al. (1997).

For both models it was considered that runoff is generated only by the drainage area comprised of the roadbed and corresponding to $300 \mathrm{~m}^{2}$, allowing for a water infiltration rate in the roadbed $\left(\mathrm{INF}_{\mathrm{R}}\right)$ of $1 \mathrm{~mm} \mathrm{~h}^{-1}$. The considered infiltration basin was rectangular shaped with a width $\left(\mathrm{L}_{\mathrm{B}}\right)$ of $6 \mathrm{~m}$ and downstream $\left(\mathrm{s}_{1}\right)$ and upstream $\left(\mathrm{s}_{2}\right)$ slope declivities of 1 and $0.5 \mathrm{~m} \mathrm{~m}^{-1}$ respectively.

In the comparative analysis of the models, were considered precipitation data from the João Pinheiro and São Gonçalo do Abaeté towns, both from Minas Gerais State, Brazil, and localized into of the Paracatu watershed.

\section{RESULTS AND DISCUSSION}

Figure 2 shows a comparison between the $\mathrm{V}_{\mathrm{B}}$ for different values of $\mathrm{INF}_{\mathrm{B}}$ calculated by the model developed by Silva (2009) $\left(\mathrm{S}_{\mathrm{M}}\right)$ and those calculated by the model developed by Pruski et al. (1997) (SSWB). Relations considering different values of $\mathrm{T}$ were obtained for each $\mathrm{INF}_{\mathrm{B}}$ studies with regard to precipitation conditions in the municipality of João Pinheiro. The lines shown in the figure relate the identity function and the linear regression fitted to the $V_{B}$ points calculated by the $S_{M}$ model versus the $V_{B}$ calculated by the SSWB model.

In the $S_{\mathrm{M}}$ model, the effect of overlapping runoff events on volumes stored during each day of the series is taken into account and, consequently, it influences the volume required for the infiltration basin. The SSWB model only takes into consideration one event associated with the determined return period without taking into account the fact that there are many events throughout the series where the runoff volume does not completely infiltrate the soil during a given day, and that the infiltration of volumes over a rainy season may represent a more critical condition for the design of the infiltration basin than the volume resulting from a single rainfall, as considered by the SSWB model.

The comparison between the models for different $\mathrm{INF}_{\mathrm{B}}$ values shows that lower $\mathrm{INF}_{\mathrm{B}}$ values resulted in greater differences in the $\mathrm{V}_{\mathrm{B}}$ calculated by the two models. For a $\mathrm{INF}_{\mathrm{B}}$ of $2 \mathrm{~mm} \mathrm{~h}^{-1}$, it was noted that the $V_{B}$ values obtained by the $S_{M}$ model estimated higher $\mathrm{V}_{\mathrm{B}}$ values, the magnitude of which was 2.65 times higher on average than the values obtained by the SSWB. For INF $\mathrm{IB}_{\mathrm{B}}$ of 5, 10, 15 and $20 \mathrm{~mm} \mathrm{~h}^{-1}$, differences of 1.48, $1.21,1.14$ and 1.11 times greater were noted on average, respectively.

This behavior is the result of a more accentuated effect of overlapping runoff events when $\mathrm{INF}_{\mathrm{B}}$ is lower, making the volumes stored in the basin and, consequently, the value of $\mathrm{V}_{B}$ calculated by the $S_{M}$ model larger. Because The SSWB model does not consider this characteristic, the difference between the $V_{B}$ values calculated by the models increases.

Studies relating the water infiltration rate into the soil at the bottom of the infiltration basin are still very scarce. However, it is anticipated that consideration of smaller values of this variable are more representative for the majority of the cases, even when dealing with infiltration basins constructed of soils with good infiltration capacity. This affirmation is based on the fact that there are processes which expressively interfere in the reduction of basin infiltration rates, such as: i) compaction of the soil at the base by tractor tires during construction such as illustrated by Miranda et al. (2009) and from the weight of the basin water (Ma \& Spalding, 1997); and ii) soil surface sealing by the suspended solids accumulation (Lassabatere et 

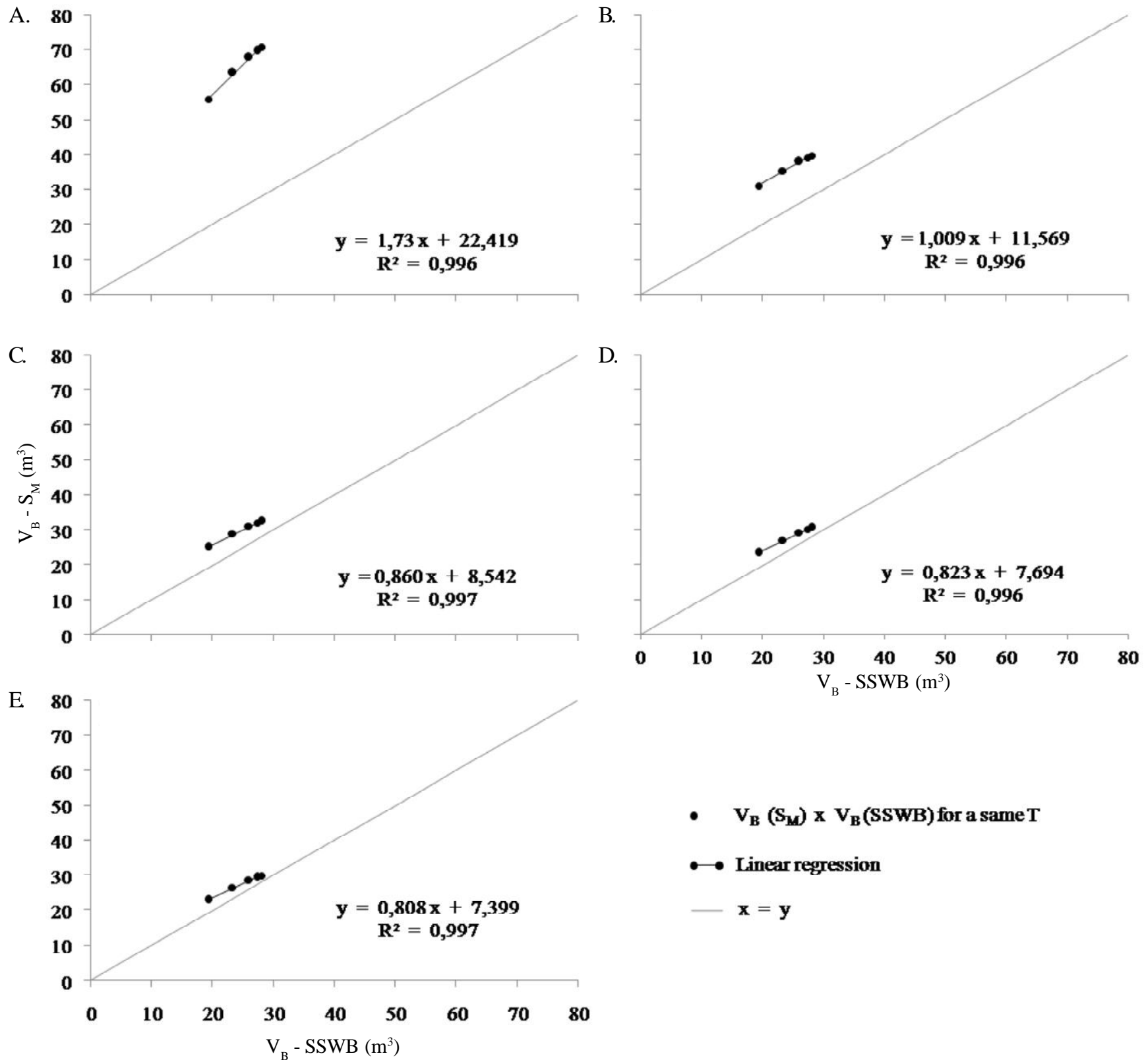

Figure 2. Volumes required for the infiltration basin calculated by the $S_{M}$ model, considering the $I N F_{B}$ of 2 (A), 5 (B), 10 (C), 15 (D) and $20 \mathrm{~mm} \mathrm{~h}^{-1}$ (E) and by the SSWB model considering the return periods of 5, 10, 15, 18 and 20 years with the precipitation conditions in the municipality of João Pinheiro, MG

al., 2010; Dechesne et al., 2004) like organic matter (Cannavo et al. (2010), silt and clay particles transported from the road to the infiltration basin, biofilm development by microbial growth on bottom of the basin and precipitation of calcium carbonate due to increase of $\mathrm{pH}$ caused by algal activity (Ma \& Spalding, 1997).

When comparing the models for different values of $\mathrm{T}$, it was noted that for different values of $\mathrm{INF}_{\mathrm{B}}$, there was a linear trend between the $\mathrm{V}_{\mathrm{B}}$ values obtained by the models (Figure 2). For a $\mathrm{INF}_{\mathrm{B}}$ of $2 \mathrm{~mm} \mathrm{~h}^{-1}$, the $\mathrm{V}_{\mathrm{B}}$ values obtained by the $\mathrm{S}_{\mathrm{M}}$ showed an increased difference in relation to those obtained by the SSWB model with an increase in $\mathrm{T}$, represented by the angular coefficient of the equation greater than 1 . With the increase in $\mathrm{INF}_{\mathrm{B}}$ the angular coefficients of the regression equations decrease, also for $\mathrm{INF}_{\mathrm{B}}$ values of 10,15 and $20 \mathrm{~mm} \mathrm{~h}^{-1}$ less than
1 , indicating the reduction of differences between the models with increases in $\mathrm{T}$.

The trend highlighted how the difference between the obtained values increases with the return period for lower $\mathrm{INF}_{\mathrm{B}}$ values due to the differences in procedures used to estimate $\mathrm{V}_{\mathrm{B}}$. In the SSWB model, the value of $\mathrm{V}_{\mathrm{B}}$ is estimated considering a single rainfall associated with the return period in question, estimated by the equation of intensity, duration and frequency (Eq. 3), whereas in the $S_{M}$ model the value of $V_{B}$ is calculated based on the application of the Gumbel distribution for annual series of maximum stored volumes.

The $V_{B}$ value calculated by SSWB model does not change with the variation of $\mathrm{INF}_{\mathrm{B}}$ at the bottom of the basin. In contrast, the $S_{M}$ model presents an expressive sensitivity to variation in $\mathrm{INF}_{\mathrm{B}}$, which is more pronounced for lower values of this variable 
(Silva, 2009). Thus, for the same value of $T$, while the $V_{B}$ value remains constant using the SSWB model, there is a considerable variation in the $S_{M}$ model, which is more pronounced for lower values of $\mathrm{INF}_{\mathrm{B}}$.

Comparison between the $\mathrm{V}_{\mathrm{B}}$ values obtained by the SSWB and $\mathrm{S}_{\mathrm{M}}$ models was also performed for precipitation conditions characteristic of municipality of São Gonçalo do Abaeté (Figure 3 ). For these conditions, the $V_{B}$ values obtained by the $S_{M}$ model were higher than the SSWB model only for the $\mathrm{INF}_{\mathrm{B}}$ of $2 \mathrm{~mm} \mathrm{~h}^{-1}$.

The difference between the results obtained for the two locations studied is due to differences in precipitation conditions specific to each location, which influenced both the values of $\mathrm{V}_{\mathrm{B}}$ obtained by the $\mathrm{S}_{\mathrm{M}}$ model and those obtained
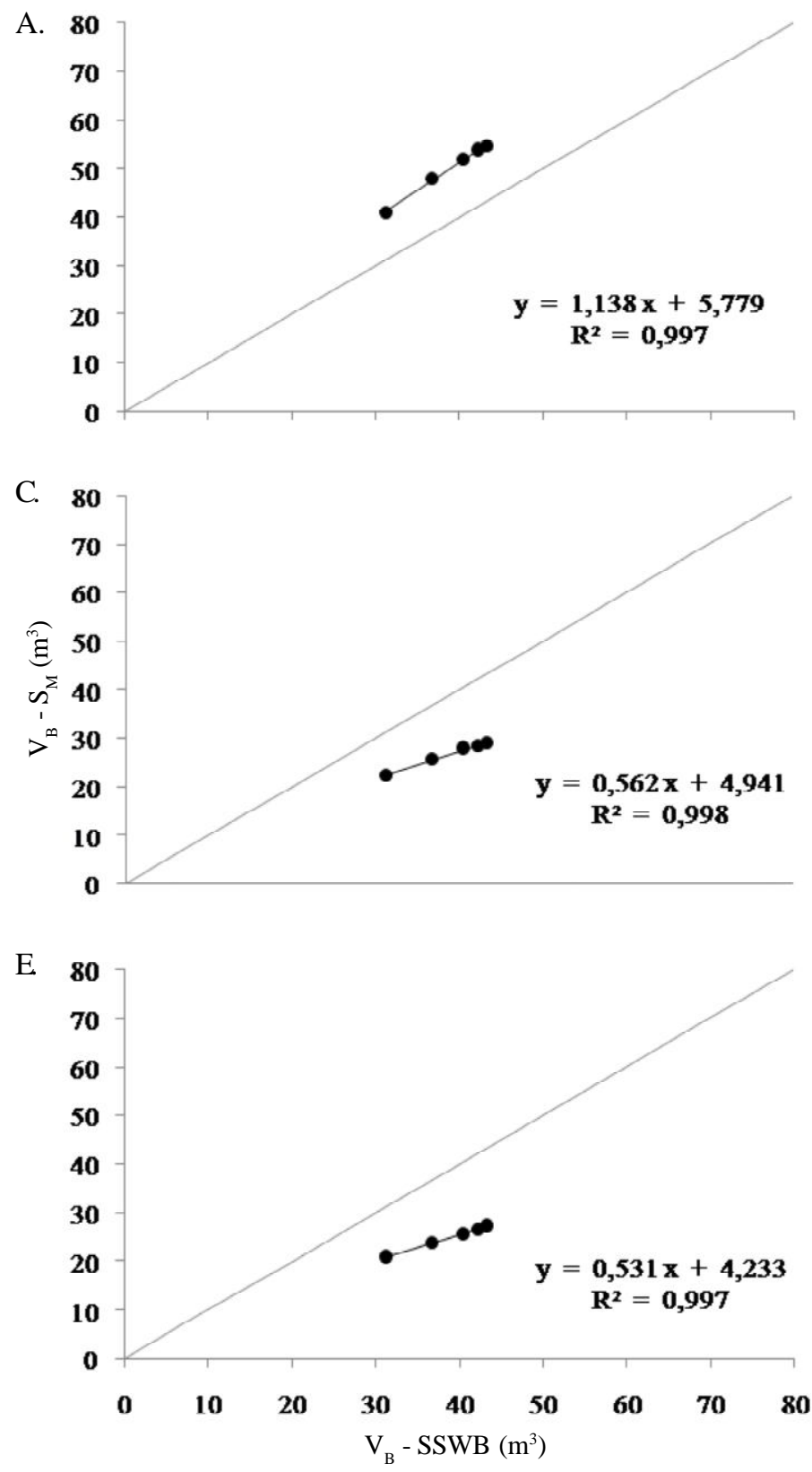

by the SSWB model. While the $\mathrm{V}_{\mathrm{B}}$ values calculated by the $\mathrm{S}_{\mathrm{M}}$ model were higher for the conditions in Joao Pinheiro, the values obtained by the SSWB were greater for the precipitation conditions in São Gonçalo do Abaeté. Thus, only when the $\mathrm{INF}_{\mathrm{B}}$ was $2 \mathrm{~mm} \mathrm{~h}^{-1}$ were values calculated by the $\mathrm{S}_{\mathrm{M}}$ model greater than those obtained by the SSWB model.

Figure 4 presents the precipitation profiles used by the SSWB model obtained for São Gonçalo do Abaeté and João Pinheiro considering an event with a return period of 10 years and roadbed infiltration rate of $1 \mathrm{~mm} \mathrm{~h}^{-1}$. In São Gonçalo do Abaeté the critical rainfall duration, i.e., duration capable of causing the maximum runoff, is $28.1 \mathrm{~h}$, corresponding to a total precipitation depth of $152.7 \mathrm{~mm}$, while for João Pinheiro the critical duration of rainfall is $13.3 \mathrm{~h}$ and corresponds to a

B.

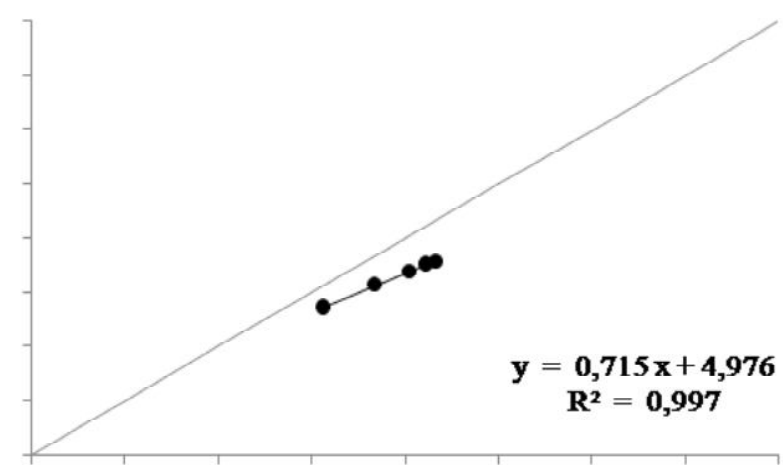

D.

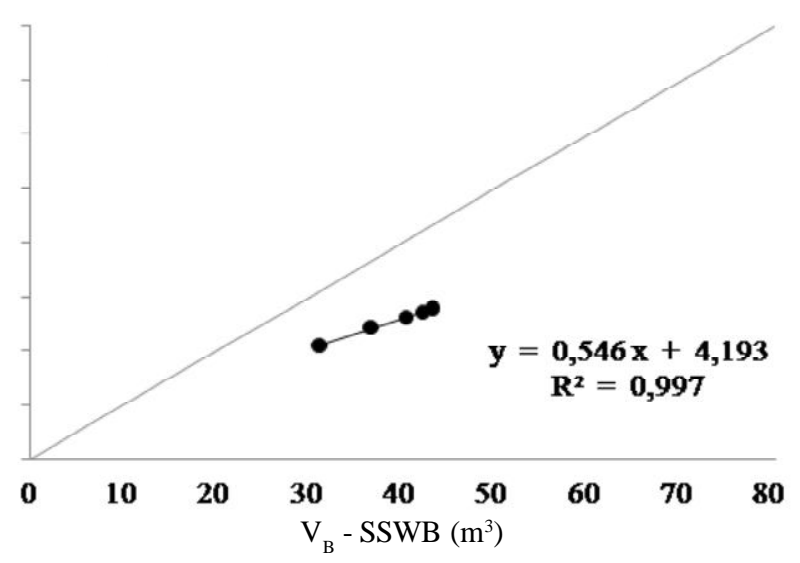

B.

- $\quad V_{B}\left(S_{M}\right) \times V_{B}(S S W B)$ for a same $T$

- - Linear regression

$\mathbf{x}=\mathbf{y}$

Figure 3. Volumes required for the infiltration basin calculated by the $S_{M}$ model, considering a INF ${ }_{B}$ of $2(A), 5(B), 10$ (C), 15 (D) and $20 \mathrm{~mm} \mathrm{~h}^{-1}$ (E) and SSWB model considering the return periods of 5, 10, 15, 18 and 20 years and the precipitation conditions in São Gonçalo do Abaeté 


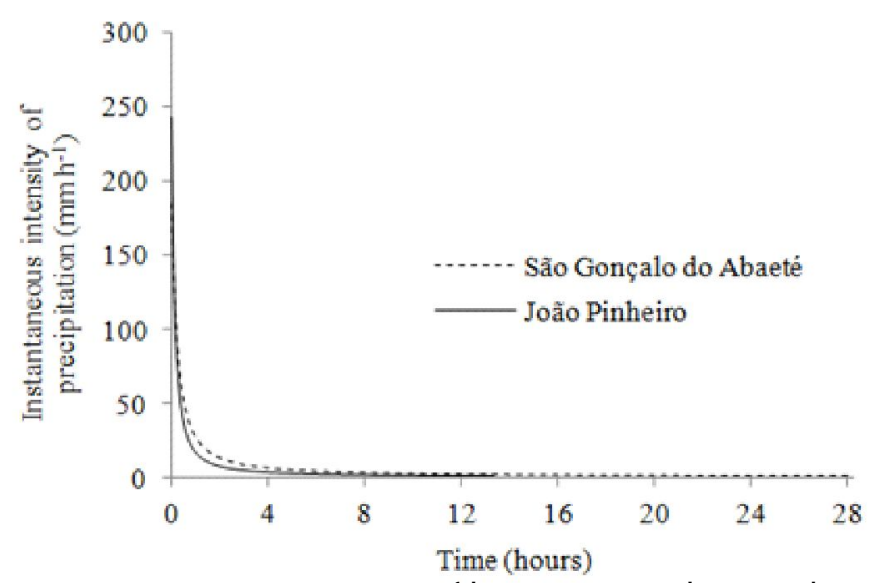

Figure 4. Precipitation profiles corresponding to the maximum expected rainfall for a return period of 10 years in the municipalities of São Gonçalo do Abaeté and João Pinheiro

precipitation depth of $93.3 \mathrm{~mm}$. Thus, the precipition depth in São Gonçalo do Abaeté for the critical condition, i.e. that which results in maximum runoff, is about $64 \%$ greater than observed in João Pinheiro.

With regard to the differences between $\mathrm{V}_{\mathrm{B}}$ values obtained by the $\mathrm{S}_{\mathrm{M}}$ model, the fact that João Pinheiro presented higher $V_{B}$ values is due to the expressive effect of events overlapping throughout the series that was noted in this locality. An analysis of the historical precipitation series from the two sites showed that the average annual rainfall and the maximum rainfall event associated with a return period of 10 years are more critical to the design of the basin for the conditions of João Pinheiro than for São Gonçalo do Abaeté.

The average annual precipitation calculated for the municipality of João Pinheiro was $1164.5 \mathrm{~mm}$ and corresponds to a value of roughly $29 \%$ greater than the value calculated for São Gonçalo do Abaeté, which was only $900.9 \mathrm{~mm}$. With respect to an isolated rainfall event associated with a return period of 10 years (allowing for the use of the precipitation series used in the $\mathrm{S}_{\mathrm{M}}$ model), the value obtained for the conditions in Joao Pinheiro was about $10 \%$ higher, i.e., while for this location the value was $113.9 \mathrm{~mm}$ and the corresponding value in São Gonçalo do Abaeté was $103.1 \mathrm{~mm}$. This data indicates that from the $V_{B}$ values obtained (Figures 2 and 3), the effect of overlapping events is more pronounced when the rain volume and magnitude of these are greater, especially for low values of $\mathrm{INF}_{\mathrm{B}}$.

The effect of overlapping runoff events can be better understood when analyzing Figure 5. In this figure are show on the average number (considering a data series of 50 years) of rain days per month and average number of days per month when it rainy while the basin still had rainwater stored from previous days. According to Figure 5A the average number of rainy days in João Pinheiro is more than the average number of rainy days in São Gonçalo do Abaeté (Figure 5B). The Figure 5 also shows that the average number of rainy days occurring when the basin still contained rainwater remaining from previous events is greater for João Pinheiro, for all $\mathrm{INF}_{\mathrm{B}}$ values.

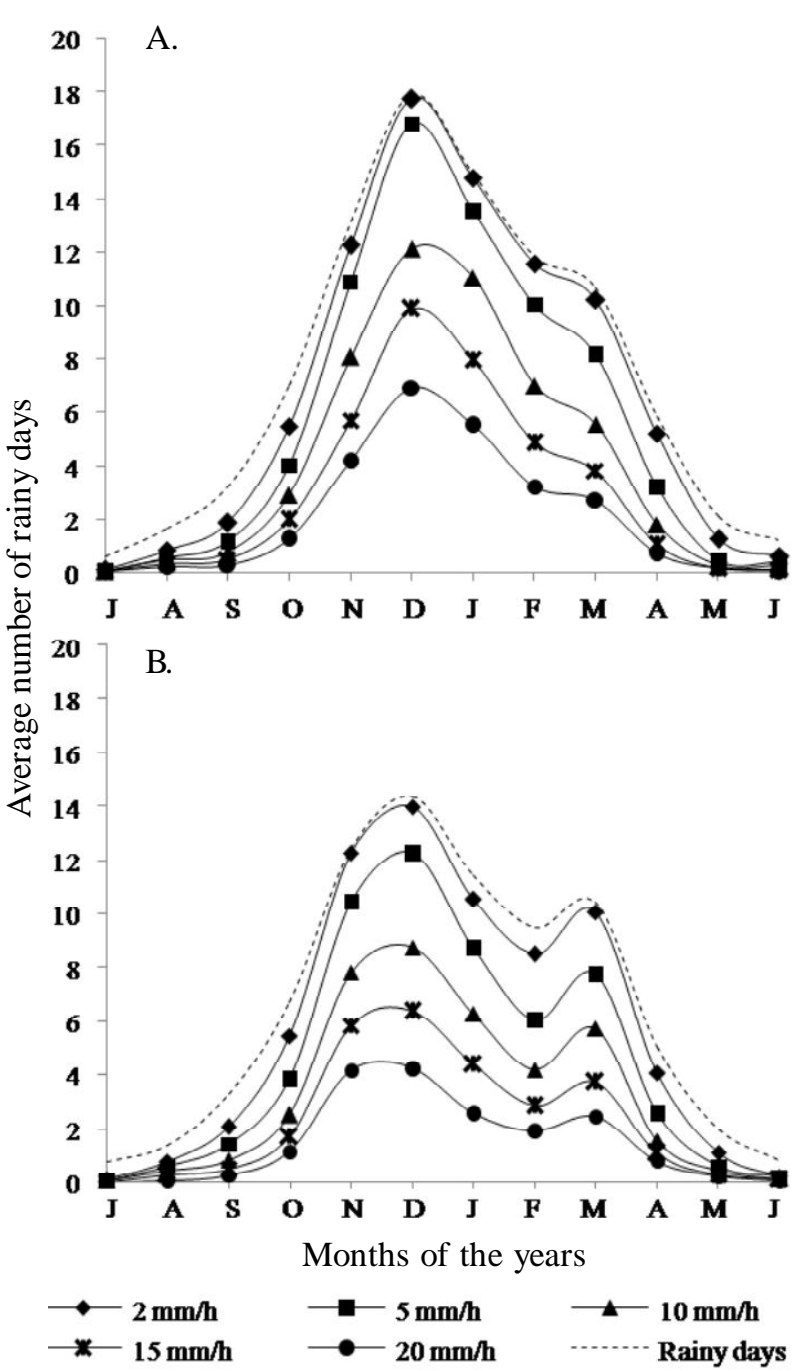

Figure 5. Average number of rainy days per month and average number of days per month when it rained while the basin still had rainwater stored remaining from previous days, with different values of $\mathrm{INF}_{\mathrm{B}}$ for the precipitation conditions of the municipalities of João Pinheiro (A) and São Gonçalo do Abaeté (B)

It can also be noted, from an analysis of Figure 5 that in the period from December to February in João Pinheiro for a $\mathrm{INF}_{\mathrm{B}}$ of $2 \mathrm{~mm} \mathrm{~h}^{-1}$ the infiltration basin is never completely empty (Number of rainy days equal to the number of days when the rain occurs with basin still had rainwater stored from the previous days), while in São Gonçalo do Abaeté, there are years when the basin is found empty, which characterizes the pronounced overlapping effect for João Pinheiro.

\section{Conclusions}

1. For soils with low water infiltration rate through the basin bottom soil $\left(\mathrm{INF}_{\mathrm{B}}\right)$ the method proposed by Silva (2009) leads to higher required volumes values of infiltration basins $\left(\mathrm{V}_{\mathrm{B}}\right)$, independently of location and return period considered.

2. For soils with high $\mathrm{INF}_{\mathrm{B}}$, the $\mathrm{V}_{\mathrm{B}}$ values calculated by the model developed by Silva (2009) tends to be higher than the 
model proposed by Pruski et al. (1997), when the events overlap effect is higher.

3. For soils with high $\mathrm{INF}_{\mathrm{B}}$, the return period effect in the $\mathrm{V}_{\mathrm{B}}$ values is higher in the model proposed by Pruski et al. (1997) than the model proposed by Silva (2009).

\section{ACKNOWLEDGMENTS}

The authors would like to thank Conselho Nacional de Desenvolvimento Científico e Tecnológico - CNPq (Brazil), and Fundação de Amparo à Pesquisa do Estado de Minas Gerais FAPEMIG (Minas Gerais state, Brazil), for providing necessary funds to conduct this work.

\section{LiTERATURE CITED}

Baena, L. G. N.; Pruski, F. F.; Moreira, M. C.; Souza, V. B. C.; Zanetti, S. S.; Oliveira, V. P. S. Programa computacional para geração de séries de dados climáticos. Revista Engenharia na Agricultura, v.13, p.210-220, 2005.

Cannavo, P.; Vidal-Beaudet, L.; Béchet, B.; Lassabatère, L.; Charpentier, S. Spatial distribution of sediments and transfer properties in soils in a stormwater infiltration basin. Journal of Soils Sediments, v.10, p.1499-1509, 2010.

Carvalho, W. L.; Cruz, R. O. M.; Camara, M. T.; Aragão, J. J. G. Rural school transportation in emerging countries: The Brazilian case. Research in Transportation Economics, v.30, p.1-9, 2010.

Crossley, C. P.; Kibiwot, V. N.; Reynolds, A. J.; Rickson, R. J. Rut formation and rolling resistance on earth roads. Journal of Agricultural Engineering Research, v.78, p.99-107, 2001.

Dechesne, M.; Barraud, S.; Bardin, J. P. Indicators for hydraulic and pollution retention assessment of stormwater infiltration basins, Journal of Environmental Management, v.71, p.371-380, 2004.

Egan, A. F. Forest roads: Mere soil and water don't mix. Journal of Forest, v.97, p.18-21, 1999.

Forsyth, A. R.; Bubb, K. A.; Cox, M. E. Runoff, sediment loss and quality from forest roads in a southeast Queensland coastal plain Pinus plantation. Forest Ecology and Management, v.221, p.194-206, 2006.

Gallego, E.; Moya, M.; Piniés, M.; Ayuga, F. Valuation of low volume roads in Spain. Part 1: Methodology development. Biosystems Engineering, v.101, p.123-134, 2008a.

Gallego, E.; Moya, M.; Piniés, M.; Ayuga, F. Valuation of low volume roads in Spain. Part 2: Methodology validation. Biosystems Engeneering, v.101, p.135-142, 2008b.

Grace III, J. M. Sediment movement from forest road systems. Resource, v.9, p.13-14, 2002.

Griebeler, N. P.; Pruski, F. F.; Silva, J. M. A.; Ramos, M. M.; Silva, D. D. Model to determine the spacing between water outlets in unpaved roads. Revista Brasileira de Ciência do Solo, v.29, p.397-405, 2005.

Jungerius, P. D.; Matundura, J.; Ancker, J. A. M. Road construction and gully erosion in west Pokot, Kenya. Earth Surface Processes and Landforms, v.27, p.1237-1247, 2002.

Kite, G. W. Frequency and risk analysis in hydrology. 5.ed. Highlands Ranch: Water Resources Publications, 1988. 257p.
Lassabatere, L.; Angulo-Jaramillo, R.; Goutaland, D.; Letellier, L.; Gaudet, J. P.; Winiarski, T.; Delolme, C. Effect of the settlement of sediments on water inûltration in two urban infiltration basins. Geoderma, v. 156, p.316-325, 2010.

Lugo, A. E.; Gucinski, L. H. Function, effects, and management of forest roads. Forest Ecology and Management, v.133, p.249-262, 2000.

Ma, Li; Spalding, R. F. Effects of artificial recharge on ground water quality and storage recovery. Journal of the American Water Resources Association, v.33, p.561-572, 1997.

Machado, C. C.; Garcia, A. R.; Silva, E.; Fontes, A. M. Comparison of erosion rates in forest roads applying the WEPP model (Water Erosion Prediction Project) modified with reference to experimental measurements. Revista Árvore, v.27, p.295-300, 2003.

Miranda, A. C. R.; Silva, D. P.; Mello, E. L.; Pruski, F. F. Implantação, avaliação e monitoramento de práticas mecânicas para a conservação de solo e água. In: Fernando Falco Pruski. (Org.). Conservação do solo e água: Práticas mecânicas para o controle de erosão hídrica. 2 ed. Viçosa: Editora UFV, 2009. Cap.8, p.216-259.

Motha, J. A.; Wallbrink, P. J.; Hairsine, P. B.; Grayson, R. B. Unsealed roads as suspended sediment sources in an agricultural catchment in south-eastern Australia. Journal of Hydrology, v.286, p.1-18, 2004.

Nyssen, J.; Poesen, J.; Moeyersons, J.; Luyten, E.; VeyretPicot, M. ; Deckers, J.; Haile, M.; Govers, G. Impact of road building on gully erosion risk: a case study from the northern Ethiopian highlands. Earth Surface Processes and Landforms, v.27, p.1267- 1283, 2002.

Oliveira, V. P. S.; Zanetti, S. S.; Pruski, F. F. CLIMABR Part II: Generation of precipitation profile. Revista Brasileira de Engenharia Agrícola e Ambiental, v.9, p.355-349, 2005 a.

Oliveira, V. P. S.; Zanetti, S. S.; Pruski, F. F. CLIMABR Part I: Model for generation of synthetic series of precipitation. Revista Brasileira de Engenharia Agrícola e Ambiental, v.9, p.356-363, 2005b.

Pruski, F. F. Conservação de solo e água: Práticas mecânicas para o controle da erosão hídrica. 2.ed. Viçosa: UFV, 2009. 279 p.

Pruski, F. F.; Ferreira, P. A.; Ramos, M. M.; Cecon, P. R. Model to design level terraces. Journal of Irrigation and Drainage Engineering, v.123, p.8-12, 1997.

Rummer, B.; Stokes, B.; Lockaby, G. Sedimentation associated with forest road surfacing in a bottomland hardwood ecosystem. Forest Ecology and Management, v.90, p.195-200, 2000.

SCS - Soil Conservation Service. National engineering handbook, section 4: Hydrology. Washington: USDA, 1972. 115p.

Silva, D. P. Modelo de dimensionamento de bacias de acumulação para estradas. Viçosa: UFV, 2009. 57p. Dissertação Mestrado

Thompson, M.; Sessions, J.; Boston, K.; Skaugset, A.; Tomberlin, D. Forest road erosion control using multiobjective optimization. Journal of the American Water Resources Association, v.46, p.712-723, 2010.

Zanetti, S. S.; Pruski, F. F.; Moreira, M. C.; Sediyama, G. C.; Silva, D. D. Software for generation of synthetic series of precipitation. Engenharia Agrícola, v.25, p.96-104, 2005. 